\title{
Okul Öncesi Dönem Çocuklarının Davranışlarının Öz Düzenleme Becerileri Yönünden İncelenmesi
}

\section{Investigation Of Preschool Children' Behaviors In Terms Of Self Regulation Skills}

\author{
Kevser TOZDUMAN YARALI*, F. Abide GÜNGÖR AYTAR**
}

\begin{abstract}
Öz: Bu araştırma, öz düzenleme becerisi gelişmemiş çocukların davranış problemlerini incelemek amacıyla yapılmıştır. Araştırma, karma modelde tasarlanmıştır. Önce nicel sonra nitel modelin kullanıldığı açımlayıcı tür kullanılmıştır. Araştırmanın verileri Ankara'nın merkezinde bulunan iki anaokuluna devam eden çocuklardan toplanmıştır. Araştırmanın nicel boyutuna 64 çocuk katılmış olup, nitel boyutuna ait veriler öz düzenleme becerisi gelişmemiş sekiz çocuktan elde edilmiştir. Araştırmanın nicel boyutunda okul öncesi öz düzenleme becerileri ölçeği kullanılmış olup, nitel boyutunda görüşme tekniği ve "var olmayan bir hayvan çiz" testi kullanılmıştır. Çalışmanın nicel boyutu için tarama deseni kullanılmış ve SPSS. 16 paket programı kullanılarak betimsel analiz yapılmıştır. Nitel boyutu için ise durum deseni kullanılmış ve içerik analizi yapılmıştır. Araştırmada, öz düzenleme becerileri gelişmemiş çocukların daha çok, kurallara uymama ve grup dinamiğini bozma kategorisine ait davranışlarda problem yaşadıkları sonucu elde edilmiştir. Çocukların çizdikleri var olmayan bir hayvan resminde ise sekiz çocuktan yedi çocuğun saldırganlık içeren çizim ya da anlatımlara yer verdikleri belirlenmiştir.

Anahtar Kelimeler: Öz düzenleme, davranış problemleri, okul öncesi dönem
\end{abstract}

\begin{abstract}
The purpose of this study is to investigate the behavioral problems of children whose selfregulation is not developed. This study was designed in the mixed method. The exploratory design was used in which first qualitative and later quantitative models were included. The data of the study were collected from children who attended to kindergartens at center in province of Ankara during the data collection. The quantitative dimension of the study included 64 children as participants while the qualitative data were gathered from eight children whose self-regulation was not developed. In the quantitative part of the study, preschool self-regulation scale was used while in the qualitative part interview technique and "nonexistent animal drawing test" were used. For the quantitative part of the study, survey design was used, and a descriptive analysis was conducted through SPSS 16 package program. At the end of the study, the children whose self-regulatory skills were not developed were mostly found as experiencing problems in violating the rules and ruining the group dynamics categories. In the nonexistent animal drawings of children seven children out of eight were found to be including expressions showing aggression.
\end{abstract}

Keywords: Self-regulaion, behavior disorders, preschool period

Giriş

Öz düzenleme, bireyin bilişsel, motivasyonel ve davranışsal olarak öğrenme sürecini kontrol etmesi anlamına gelmektedir (Zimmerman, 2000). Aynı zamanda bireyin içsel ve dışsal taleplere etkili/yerinde cevaplar/tepkiler verebilmesi için dikkatin ve davranışın düzenlenmesi şeklinde de tanımlanabilir (Raffaelli, Crockett ve Shen, 2005). Öz düzenlemenin iki yönü vardır: çocuğun hem ne yapmaması gerektiğini hem de ne yapması gerektiğini kapsar. Whitebread ve diğerleri (2004), ele aldıkları kuramsal çerçevede, okul öncesi çocukları için öz düzenlemenin, üstbilişsel bilgi, üstbilişsel düzenleme ve duygusal motivasyonel düzenleme olmak üzere üç boyutu olduğunu belirtmişlerdir. Üstbilişsel bilgi, bilginin farkında olmak

\footnotetext{
*Araş. Gör., Kırklareli Üniversitesi, Sağlık Yüksekokulu, Çocuk Gelişimi Bölümü, Türkiye, e-posta: kevserizmir@gmail.com

**Prof. Dr. 2, Gazi Üniversitesi, Eğitim Bilimleri Fakültesi, Çocuk Gelişimi Bölümü, Türkiye, e-posta: abidegungor@gmail.com
} 
anlamına gelir. Üstbilişsel düzenleme, bilgiyi kullanarak plan yapmayı, planı uyuglama esnasında süreci izlemeyi ve kontrol etmeyi ve süreci değerlendirmeyi içerir. Duygusalmotivasyonel düzenleme ise, öğrenme sürecinde bireyin duygularını ve motivasyonel durumlarını izlemesi ve kontrol etmesine yöneliktir. Öz düzenleme becerisi gelişmiş bir çocuk, uygun olmayan bir davranışı engeller, devamında uygun olan bir davranış sergiler. Öz düzenleme becerisi gelişmiş çocuklar zevki erteleyebilirler, saldırgan davranışı bırakabilirler ve duygularını kontrol altına alarak olumlu davranışlar sergilerler (Bodrova ve Leong, 2013).

Bireyin yaşamındaki riskli davranışları engellemesine etki eden en önemli faktörlerden biri öz düzenlemedir. Öz düzenleme bir çeşit kişisel navigasyondur. Bu kişisel navigasyon, yaşam boyu karşılaşılan çeşitli olaylarla nasıl başa çıkılacağını içerir ve bireyin amaçlarını, planlarını ve inançlarını da kapsayan kişisel kontrolünü ifade eder (Sternberg ve SpearSwerling, 1998). Öz düzenleme bireysel boyutun dışında, toplumsal hayatın da önemli bir faktörüdür (Polnariev, 2006). Gelişmemiş öz düzenleme becerisinin saldırganlık, impulsiflik ve karşı gelme gibi birçok davranış sorunuyla ilişkisi vardır. Davranış sorunları ise akran çatışması ve negatif öğretmen-çocuk ilişkisine neden olabilmektedir. Öz düzenleme becerisi gelişmemiş çocukların akran reddi ve akademik zorluklar yaşadıkları bilinmektedir (Eisenberg, Pidada ve Liew, 2001; Mccelland ve Tominey, 2011; Montroy ve diğerleri, 2014). Okul öncesi dönemde önleyici kontrol becerileri yetersiz, tepki düzeyleri yüksek ve güç kontrol edilen çocukların ergenlik dönemindeki sosyal süreçlerde de kendilerini ifade etmede sorun yaşadıkları görülmektedir (Eisenberg, Smith ve Spinrad, 2011).

Çocuk, bulunduğu gelişim dönemindeki görevleri yerine getiremez, karşılaştığ problemlere etkili çözümler bulamaz ise çocukta uyum ve davranış sorunları görülebilir (Yörükoğlu, 2008). Davranış problemlerini Honig (1997) çocukların toplumsal kuralları ve yetişkinlerin koyduğu kuralları algılamasına rağmen kasıtlı olarak bu kuralların aksine hareket etmesi olarak tanımlarken (aktaran Akduman, 2014), DSM V davranış sorunlarını; başkalarının temel haklarını veya toplumsal norm ya da kuralları ihlal eden tekrarlayıcı ve tutarlı davranış örüntüsü olarak ele almaktadır (APA, 2013). Çocuğun çevresiyle yaşadığı sosyal olumsuz etkileşimlerinin nedeni ve devamı olan davranış problemleri, çocuğun uyumunu ve okul başarısını da etkilemektedir (Kanlıkılıçer, 2005). Okul öncesi dönemde görülen davranış problemlerinin, saldırganlık, karşı gelme, kıskançlık, yalan söyleme, korku, öfke, çalma, altını 1slatma, dışkı kaçırma, parmak emme, tırnak yeme, kekemelik, yeme bozuklukları, uyku bozuklukları, endişeli ve ağlamaklı olma, dikkatsizlik, aşırı hareketlilik boyutlarında olduğu bilinmektedir (Akduman, 2014; Çağdaş ve Seçer, 2002; Kanlıkılıçer, 2005). Kandır (2000), okul öncesi öğretmenlerinin çocuklarda rastladıkları davranış sorunlarına ilişkin bilgi ve tutumlarını incelediği çalışmasında, öğretmenlerin \%42.4'ünün çocuklarda en sık karşılaştıkları davranış probleminin saldırganlık olduğu sonucunu elde etmiştir.

Öz düzenleme becerileri konusunda da Raffaelli ve diğerleri (2005), yaptıkları boylamsal çalışmada erken yaşlarda kazanılan öz düzenleme becerisinin orta çocukluk ve ergenlik döneminde de istikrarlı olarak devam ettiğini bulmuşlardır. Yapılan çalışmalar, öz düzenleme becerileri gelişmiş çocukların akademik hayatlarında daha başarılı olduklarını, çünkü derslerinde ve hayatlarında karşılaştıkları problemlerde kendilerine daha fazla güvendiklerini ve gayret gösterdiklerini ortaya çıkarmıştır (Mcclelland ve Tominey, 2011; Zimmerman, 1990). Bunun aksine, öz düzenlemeleri zayıf olan çocuklar, zihinsel gelişimde gecikmeler gösterebilir ve okul öncesi yıllarda davranış sorunları yaşayabilirler. Bu çocuklar uzun süreli sorunlar açısından risk altındadırlar (Eisenberg ve diğerleri, 2004). Bu nedenle, okul öncesi dönemde kazandırılan becerilerle çocuklar, kendilerini, yeterlilikleri ve yetersizlikleri ile tanıan, başkalarıyla etkili iletişim ve dostluk kurabilen, araştıran, yaratıcı, kendiyle ve çevresiyle barışık bireyler haline gelebilirler (Senemoğlu, 1994). Nota, Soresi ve Zimmerman (2004), çalışmalarında çocukların öz düzenlemeli öğrenme stratejilerinin okul başarılarını yordadığını belirtmişlerdir. Öz denetim ve öz düzenleme becerileri gelişmemiş kişilerin, yaşamlarında alkolizm, şuça karışma, ilaç bağımlılığı, kumar, eğitim sürecinde başarısızlık ve birçok sosyal problem yaşamaya daha eğilimli olduğu bilinmektedir (Hrbackova ve Safrankova. 2016). 
Çocukta davranış bozukluklarını ortaya çıkaran nedenlerin kalıtım, fiziksel nedenler, temel ihtiyaçların doyurulmaması, çevresel ve sosyo- ekonomik faktörler ve hatalı anne- baba tutumları (Berk, 2013) gibi etkenler tarafından belirlendiği belirtilmesine karşın çocukların davranış problemlerine yönelik çalışmaların daha çok anne-baba tutumları bağlamında incelendiği görülmektedir. (Alisinanoğlu ve Kesicioğlu, 2010; Aunola ve Nurmi 2005; Dursun, 2010; Livanage, 2003)

Ülkemizde öz düzenlemeye yönelik çalışmaların sayısı az olmakla birlikte (Ertürk Kara ve Gönen 2015; Fındık Tanrıbuyurdu, 2012), öz düzenleme becerisi gelişmemiş çocukların davranış sorunlarını inceleyen bir çalışma da bulunmamaktadır. Öz düzenleme becerisi gelişmemiş çocuklar problemli davranışlar göstermeye eğilimli olduğundan (Montroy ve diğerleri, 2004), bu çalışmada, öz düzenleme becerisi gelişmemiş çocukların davranışlarının incelenmesi amaçlanmıştır. Bu amaç doğrultusunda aşağıdaki sorulara cevap aranmıştır:

1. Çocukların yaşlarına göre öz düzenleme ölçeği puanlarının dağılımı nasıldır?

2. Öz düzenleme ölçeğinden düşük puan alan çocukların cinsiyet ve yaşlara göre dağılımı nasildir?

3. Öz düzenleme becerileri gelişmemiş çocukların ne tür davranış sorunları gösterdiklerine ilişkin öğretmen görüşleri nelerdir?

4. Öz düzenleme becerileri gelişmemiş çocukların "Var olmayan bir hayvan çiz testi" resimlerinde kullandıkları ifadeler nelerdir?

\section{Yöntem}

$\mathrm{Bu}$ bölümde araştırmanın modeline, çalışma grubuna, veri toplama araçlarına, verilerin toplanması ve analizine yönelik bilgilere yer verilmiştir.

\section{Araştırmanın Modeli}

Araştırmada karma model ve açımlayıcı sıralı desen kullanılmıştır. Bu desenin amacı, nicel bulguları daha detaylı bir şekilde açıklamak için nitel verilerin kullanılmasıdır. $\mathrm{Bu}$ desende araştırmacı birinci aşamada nicel verileri toplar ve analiz eder, ikinci aşamada ise elde ettiği bulgulara göre ikinci aşamayı planlar (Creswell, 2014). Araştırmanın nicel kısmında tarama deseni kullanılmıştır. Nitel yöntem kısmında durum deseni kullanılmıştır. Araştırma durum çalışması türlerinden keşfetmeye dayalı durum çalışması kullanılarak yürütülmüştür. Durum çalışması bir ya da daha fazla durumu derinlemesine betimlemek ve araştırma soru ve konularına dikkat çekmek amacıyla yapılmaktadır (Johnson ve Chiristensen, 2014; Merriam, 2015). Bu çalışmada da durum, öz düzenleme becerisi gelişmemiş okul öncesi dönem çocuklarının davranış sorunları olarak belirlenmiştir. Araştırmada her bir durumun kendi başına bütüncül olarak ele alındığı ve daha sonra karşılaştırıldığı bütüncül çoklu durum deseni kullanılmıştır.

\section{Çalışma Grubu}

Çalışma grubunu, araştırmanın nicel boyutunda, Ankara il merkezindeki iki anaokulunda eğitime devam eden 5-6 yaş grubundan 64 çocuk oluşturmuştur. Nitel boyut için ise veriler, okul öncesi öz düzenleme ölçeğinden en düşük puan alan toplam sekiz çocuk ve dört öğretmenden elde edilmiştir. Her sınıfın öğretmeniyle, öğretmenin gözlemci rolüne dayarak, öz düzenleme ölçeğinden düşük puan alan iki çocuk için görüşme yapılmıştır. Sekiz çocuk için, toplam dört öğretmenle görüşülmüştür.

Araştırmanın nicel boyutunda rastgele olmayan örnekleme tekniklerinden uygun örnekleme yöntemi kullanılmıştır. Uygun örnekleme, mevcut, kolayca erişilebilir ve araştırmaya katılmak isteyen bireylerin örnekleme dahil edilmesi durumunda kullanılmaktadır (Johnson ve Chiristensen, 2014). Bu araştırmada da çalışmaya katılmak istemeyen çocuklar çalışma kapsamına alınmamışlardır. Araştırmaya dahil edilen çocukların sosyo ekonomik özellikleri homojen bir yapıdadır. Çocukların anne-babaları üniveriste düzeyinde öğrenime sahiptirler.

Araştırmanın nitel boyutundaki sekiz çocuk amaçlı örneklem türlerinden doğrulayıcı ve yanlışlayıc1 durum örneklemesi türüne (Patton, 2014) göre belirlenmiş ve her sınıftan öz 
düzenleme puanı en düşük iki öğrenci seçilmiştir (toplam dört sınıf dahil edilmiştir). Doğrulayıc1 veya yanlışlayıcı durum örneklemesi türünde doğrulayıcı durumlar, hâlihazırda bulunmuş temalara ve sonuçlara zenginlik ve derinlik katar, bulguların geçerliliğini arttıran ek durumlar yaratırlar (Yıldırım ve Şimşek, 2013).

Tablo 1

Çalişma Grubundaki Çocuklarin Cinsiyet ve Yaşlara Göre Dağılımı

\begin{tabular}{lllr}
\hline Değişkenler & Kategoriler & $\mathrm{n}$ & $\%$ \\
\hline \multirow{3}{*}{ Cinsiyeti } & Erkek & 40 & 62.5 \\
& Kiz & 24 & 37.5 \\
Yaş & 5 yaş & 33 & 51.6 \\
& 6 yaş & 31 & 48.4 \\
\hline
\end{tabular}

Tablo 1 incelendiğinde, araştırmanın nicel boyutunda 64 çocuk ile çalışılmıştır. Tabloya göre çocukların \% 62,5 $(\mathrm{n}=40)$ 'inin erkek, \%37.5 (n=24)'inin kız; \%51.6 (n=33)'sının 5 yaş, \% 48.4 ( $\mathrm{n}=31)^{\prime}$ ünün de 6 yaşında olduğu görülmektedir.

\section{Veri Toplama Araçları}

Araştırmanın nicel boyutunda çocukların öz düzenleme becerilerini ortaya çıkarmak için "Öz düzenleme becerileri ölçeği” kullanılmıştır. Smith-Donald ve diğerleri (2007) tarafindan geliştirilen Okul Öncesi Öz Düzenleme Ölçeği (OÖDÖ), performansa dayalı değerlendirme yapılmasını sağlayan bir ölçme aracıdır. Ölçekte yer alan uygulayıcı değerlendirme formu, uygulayıcıya, çocuğun duygu, dikkat düzeyi ve davranışlarını uygulayıcı-çocuk etkileşimine dayanarak değerlendirme imkânı sağlar. Uygulayıcı Değerlendirme Formu, 0'dan 3'e kadar puanlanarak kullanılan maddelerden oluşan rubrik tipi bir ölçme aracıdır. Ölçeğin Türkçe'ye uyarlaması Fındık Tanrıbuyurdu ve Yıldız tarafından 2012'de yapılmıştır. Yapı geçerliliği kapsamında gerçekleştirilen faktör analizi sonucunda ölçeğin iki faktörlü bir yapıda olduğu belirlenmiştir. Bu faktörler; Dikkat/Dürtü Kontrolü ve Olumlu Duygu'dur. Ölçek 16 maddeden oluşmaktadır. Ölçeğin tamamını oluşturan 16 maddeye ilişkin güvenirlik katsayısı $(\alpha) .83$ olarak belirlenmiştir. Ölçeğin Dikkat/Dürtü Kontrolü faktörünün 10 maddeye ilişkin güvenirlik katsayıs1 .88, ikinci faktör olan Olumlu Duygu için ise güvenirlik katsayıs1 .80 olarak belirlenmiştir. Okul Öncesi Öz Düzenleme Ölçeğine ait görevlerden bazıları şunlardır. Kalem tıklatma, kule toplama, oyuncak paketleme, şekerleme saklama (Fındık Tanrıbuyurdu ve Yıldız, 2014).

Araştırmanın nitel boyutunda ise öğretmenler ile görüşmeleri yapabilmek için yarı yapılandırılmış görüşme formu geliştirilmiştir. Görüşme formu hazırlanırken, soruların açık uçlu olmasına, çok boyutlu ve katılımcıları yönlendirici olmamasına, ayrıca tüm katılımcılar tarafından aynı şekilde anlaşılmasına dikkat edilmiştir. Hazırlanan sorular, kapsam ve görünüş geçerliliğini değerlendirmek için biri nitel araştırmalar konusunda doktora düzeyinde ders veren diğeri çocuk gelişimi alanında bir uzman olmak üzere, iki uzmanın görüşüne sunulmuştur. Uzmanların geribildirimleri doğrultusunda sorulara son şekli verilmiş ve görüşme formu beş sorudan oluşacak şekilde düzenlenmiştir.

Araştırmanın nitel boyutunda, veri çeşitliliğini sağlamak amacıyla görüşme tekniğine ek olarak çizim tekniği (Var olmayan Hayvan Çiz Testi) kullanılmıştır. Psiko-analatik kurama göre, çocuğun resim çalışmalarının temelinde bilinçaltında yatan istek ve korkular vardır. Çocuklar bu duygularını sembolik veya gizli ifade edebilir. Bu durum, çocukların duygu durumlarının resimleri yoluyla ölçülebileceğini ve resimlerinin de bu amaçla kullanılabileceğini göstermiştir (Halmatov, 2015; Kırışoğlu, 2005; Malchiodi; Yavuzer, 2007). Projektif bir kişilik testi olan "Var olmayan bir hayvan çiz testi" Rus Psikolog Maja Zaharovna Dukarevich tarafından geliştirilmiştir. Test bireyin kişilik özelliklerini, bazen de yaratıcılık potansiyelini belirlemeyi amaçlamaktadır. Çocuklara, yetişkinlere, hastalara ve sağlıklı insanlara uygulanabilmektedir. Birey hakkında daha detaylı araştırma yapılması gerektiğinde kullanılan 
bir testtir. Resim için A4 ebatında bir kağıt kullanılması önerilir. Resmin nasıl çizileceği konusunda herhangi bir yönlendirme yapılmamalıdır. Resmi detaylandırmak amacıyla resim bittiğinde birtakım sorular (Hayvanın ayağındaki dikenler ne işe yarıyor? Bu noktalar ne anlama geliyor? vb.) sorulmalıdır. Bununla birlikte çocuktan aşağıdaki sorulara cevap vermesi istenir.

- Bu hayvan saldirgan bir hayvan mi?

- İsim taksaydın bu hayvanın ismi ne olurdu?

- Bu hayvan neyle beslenir?

- Bu hayvan kiminle yaşıyor, yaşadığı yer nasıl?

- Bu hayvanın gerçekleşmesini istediği üç dileği neler?

- Bu hayvanın arkadaşları ve düşmanları var mı?

Testin yönergesi "Var olmayan bir hayvan resmi çizin ve ona gerçekte olmayan bir isim verin" dir. Resmin yorumlanmasında kağıdın pozisyonu, resmin boyutu, resmin kağıttaki yeri, yukar1-aşağı ekseni, sağ-sol ekseni, renk, kafa, resmin biçimi (formu), resmin zorluk derecesi, oluşturma yeteneği ve saldırganlık boyutları dikkate alınır. Değerlendirilen çocuğun saldırganlığ 1 hakkında daha fazla bilgi alınmak isteniyorsa "var olmayan kötü ve korkunç bir hayvan" çizmesi istenebilir. Bu yönerge öncelikle gizli saldırganlık eğilimini ortaya çıkarmak için bir firsattır. Aynı zamanda sosyal bir izin gibidir, bastırılmış saldırganlık eğilimini gizlemeyi gerektirmez (Halmatov, 2015).

\section{Verilerin Toplanması}

Araştırmada, çocuklara ilişkin veriler çocuklar ve öğretmenler aracılığıyla elde edilmiştir. Nicel veriler, araştırmacının çocuklar ile bire bir çalışması sonucunda toplanmıştır. Araştırmanın nicel boyutunda, çocukların öz düzenlemelerini değerlendirmek için kullanılan okul öncesi öz düzenleme ölçeği her çocuk ile gruptan bağımsız bir odada yaklaşı 25-30 dakika boyunca uygulanmıştır. Ölçeğe ait görevler çocuk ile birebir çalışılırken uygulayıcı tarafindan notlar alınmış, çocuk uygulama sonrasında sınıfa gönderilmiş ve uygulayıcı ölçeğe ait puanlamayı yapmıştır. Okul öncesi öz düzenleme ölçeğine ait veriler analiz edildikten sonra analiz sonuçlarına göre her sınıftan (toplam dört sınıf) en düşük puan alan iki çocuk belirlenmiştir.

Araştırmanın nitel boyutunda, ilk olarak öz düzenleme becerileri gelişmemiş çocukların öğretmenleri ile yarı yapılandırılmış görüşmeler yapılmıştır. Nitel görüşmeler, katılımcının herhangi bir konu hakkındaki duygularını, motivasyonlarını, mantığını, bilgilerini, inançlarını ve derin düşüncelerini elde etmek amaciyla kullanılır (Johnson ve Chiristensen, 2014). Her sınıftan öz düzenleme puanı düşük olan iki çocuğa yönelik toplam dört öğretmen ile yarı yapılandırılmış görüşmeler gerçekleştirilmiştir. Öğretmenleri yönlendirmemek amacıyla bilgi alınacak öğrencilerin öz düzenleme becerisi puanlarının düşük olduğu, öğretmenlere görüşme sonrasında söylenmiştir. Her öğretmen ile görüşmeler ortalama 15-20 dakika sürmüştür. Öğretmenlerin verdiği yanıtlar ses kaydedici cihaz kullanılarak kayıt altına alınmış, sesinin kaydedilmesini istemeyen öğretmenlerin yanıtları görüşme esnasında not tutularak kaydedilmiştir. Öz düzenleme becerileri gelişmemiş çocuklara "var olmayan bir hayvan çiz testi" uygulanmıştır. Test çocuklara dikkat dağıtıcı uyarıcılardan yalıtılmış, sessiz bir ortamda her seferinde tek çocukla çalışarak uygulanmıştır.

Araştırmanın nitel boyutunda görüşme ve çizim tekniklerinin bir arada kullanılmasıyla veri çeşitlemesi yapılmış, bu yolla çalışmanın geçerlik ve güvenirliği arttırılmaya çalışılmıştır (Merriam, 2015). Üçgenleme (çeşitleme), farklı veri kaynakları, farklı veri toplama ve analiz yöntemleri kullanılarak araştırma sonuçlarının inandırıcılığını arttırmaya yönelik çabaların bütünüdür (Yıldırım ve Şimşek, 2013).

\section{Verilerin Analizi}

Araştırmanın nicel boyutunda, verilerin analizi için SPSS 16.0 istatistik paket programı kullanılmış ve verilerin değerlendirmesinde frekans analizi yapılmıştır. Araştırmanın nitel boyutunda ise görüşme ve çizim tekniği kullanılarak elde edilecek veriler içerik analizi ve betimsel analiz yöntemiyle kodlanmıştır. Kodlamalar yapılırken araştırmanın amacı göz önüne 
alınmış ve kodlar bu doğrultuda oluşturulmuştur. Görüşmeye ait kategoriler öğretmenlerin yanıtları doğrultusunda belirlendiğinden içerik analizi yapılmıştır. Çocukların çizimlerine ait veriler ise "var olmayan bir hayvan çiz testi"nin yorumlama kriterlerine göre oluşturulduğundan betimsel analiz kullanılmıştır. Betimsel ve içerik analizinin kullanıldığ 1 çalışmalarda, bireylerden doğrudan alıntılara yer vermek geçerlilik için önemli görülmektedir (Yıldırım ve Şimşek, 2013). Veriler içerik analizi yapılırken öğretmenlerin görüşleri birer kod haline getirilmiştir. Öğretmenlerin görüşleri, belirlenen kategoriler bakımından iki ayrı araştırmacı tarafından kodlanarak kodlayıcılar arası güvenirlik analizi gerçekleştirilmiştir. Bu işlem için Kodlayıcılar Arası güvenirlik= [Görüş birliği// (Görüş birliği + Görüş ayrılığı) X 100] formülünden (Miles ve Huberman, 2015) yararlanılarak gerçekleştirilmiştir. Bu işlem sonucunda güvenirlik yüzdesi $\% 100$ olarak hesaplanmıştır. Elde edilen sonuçların aktarılabilirliğinin sağlanabilmesi için veriler ayrıntılı bir biçimde betimlenmiş ve doğrudan alıntılarla desteklenmiştir. Yapılan doğrudan alıntılarda katılımcıların gerçek isimleri gizli tutulmuş ve alıntılar kodlar yoluyla Ö1, Ç1,... biçiminde ifade edilmişlerdir.

\section{Bulgular}

Bu bölümde öz düzenleme ölçeğine ait betimsel analiz bulgularıyla birlikte, öz düzenleme becerisi gelişmemiş çocukların davranış sorunlarına ilişkin öğretmen görüşlerini analiz eden tablo ve öz düzenleme becerisi gelişmemiş çocukların çizdikleri var olmayan bir hayvan resmini analiz eden tabloya yer verilmiştir:

Tablo 2

Çocukların Yaşlarına Göre Öz Düzenleme Ölçeği Puanalarının Dağılımı

\begin{tabular}{cccccc} 
Gruplar & $\mathrm{n}$ & Min & Max & $\bar{X}$ & $\mathrm{Sd}$ \\
\hline 5 yaş & 13 & 28.00 & 42.00 & 36.76 & 3.67 \\
6 yaş & 14 & 22.00 & 43.00 & 36.21 & 6.07 \\
5 yaş & 17 & 20.00 & 44.00 & 38.88 & 2.97 \\
6 yaş & 20 & 25.00 & 48.00 & 39.35 & 8.94 \\
\hline
\end{tabular}

Tablo 3 incelendiğinde öz düzenleme ölçeğine ait betimsel istatistikler görülmektedir. Öz düzenleme ölçeğine ait en düşük puanın (20.00) beş yaş grubunda olduğu belirlenirken, en yüksek puanın (48.00) altı yaş grubuna ait olduğu görülmektedir. Puan ortalamaları incelendiğinde ise en yüksek puan ortalamasının altı yaş grubundaki bir sınıfa ait olduğu görülmektedir.

Tablo 3

Öz Düzenleme Ölçeğinden Düşük Puan Alan Çocukların Cinsiyet ve Yaşlara Göre Dağılımı

\begin{tabular}{cccccc}
\hline \multirow{2}{*}{ Kodlar } & \multicolumn{2}{c}{ Cinsiyet } & \multicolumn{2}{c}{ Yaş } & Öz Düzenleme \\
& Erkek & Kiz & 5 Yaş & 6 Yaş & Puan1 \\
\hline Ç1 & $\checkmark$ & & $\checkmark$ & & 33.00 \\
Ç2 & $\checkmark$ & $\checkmark$ & & 28.00 \\
Ç3 & $\checkmark$ & & $\checkmark$ & 25.00 \\
Ç4 & $\checkmark$ & & & $\checkmark$ & 22.00 \\
Ç5 & $\checkmark$ & & $\checkmark$ & & 32.00 \\
Ç6 & $\checkmark$ & & $\checkmark$ & & 20.00 \\
Ç7 & $\checkmark$ & & & $\checkmark$ & 33.00 \\
Ç8 & & $\checkmark$ & & $\checkmark$ & 34.00 \\
\hline
\end{tabular}

Tablo 2 incelendiğinde, dört sınıftan öz düzenleme puanı en düşük sekiz çocuk belirlenmiş ve araştırmanın nitel boyutu için çalışmaya dahil edilmişlerdir. Sekiz çocuk arasında 
en yüksek puana sahip olan çocuğun altı yaş grubundaki bir kız, en düşük puana sahip olan çocuğun ise beş yaş grubundaki bir erkek olduğu görülmektedir.

Tablo 4

Öz Düzenleme Becerisi Gelişmemiş Çocukların Gösterdikleri Davranış Sorunlarına İlişkin Öğretmen Görüşleri

\begin{tabular}{|c|c|c|c|c|c|c|c|c|c|c|}
\hline \multirow[t]{2}{*}{ Kategoriler } & \multirow[t]{2}{*}{ Kodlar } & \multicolumn{2}{|c|}{ Ö1 } & \multicolumn{2}{|c|}{ Ö2 } & \multicolumn{2}{|c|}{ Ö3 } & \multicolumn{2}{|c|}{ Ö4 } & \multirow[t]{2}{*}{ Toplam(f) } \\
\hline & & Ç1 & Ç2 & Ç3 & Ç4 & Ç5 & Ç6 & Ç7 & Ç8 & \\
\hline \multirow{2}{*}{ Saldırganlık } & $\begin{array}{l}\text { Fiziksel } \\
\text { saldırganlık }\end{array}$ & $\checkmark$ & $\checkmark$ & & & & & & & 2 \\
\hline & $\begin{array}{l}\text { Sözel } \\
\text { saldırganlık }\end{array}$ & & $\checkmark$ & & & $\checkmark$ & & & $\checkmark$ & 3 \\
\hline \multirow{5}{*}{$\begin{array}{l}\text { Kurallara } \\
\text { Uymama }\end{array}$} & $\begin{array}{l}\text { Yönergelere } \\
\text { uymama }\end{array}$ & $\checkmark$ & $\checkmark$ & & $\checkmark$ & $\checkmark$ & $\checkmark$ & & $\checkmark$ & 6 \\
\hline & $\begin{array}{l}\text { Duymazliktan } \\
\text { gelme }\end{array}$ & & & & $\checkmark$ & $\checkmark$ & $\checkmark$ & & & 3 \\
\hline & Dinlememe & & & & $\checkmark$ & & $\checkmark$ & & & 2 \\
\hline & $\begin{array}{l}\text { Sirasını } \\
\text { beklememe }\end{array}$ & & $\checkmark$ & $\checkmark$ & & & $\checkmark$ & & & 3 \\
\hline & $\begin{array}{l}\text { Sorumluluk } \\
\text { almama/yerine } \\
\text { getirmeme }\end{array}$ & & & & & $\checkmark$ & $\checkmark$ & $\checkmark$ & $\checkmark$ & 4 \\
\hline \multirow{4}{*}{$\begin{array}{l}\text { Grup } \\
\text { Dinamiğini } \\
\text { Bozma }\end{array}$} & $\begin{array}{l}\text { Çabuk } \\
\text { s1kılma/sebat } \\
\text { etmeme }\end{array}$ & $\checkmark$ & & & $\checkmark$ & $\checkmark$ & $\checkmark$ & $\checkmark$ & $\checkmark$ & 6 \\
\hline & $\begin{array}{l}\text { Arkadaşını } \\
\text { rahatsız etme }\end{array}$ & $\checkmark$ & & & & $\checkmark$ & & & $\checkmark$ & 3 \\
\hline & $\begin{array}{l}\text { Grup ya da } \\
\text { masa }\end{array}$ & & & & & & & & & 3 \\
\hline & $\begin{array}{l}\text { etkinliklerini } \\
\text { sevmeme/ } \\
\text { istememe }\end{array}$ & $\checkmark$ & & & & $\checkmark$ & $\checkmark$ & & & \\
\hline \multirow{6}{*}{$\begin{array}{l}\text { Diğer } \\
\text { Davranış } \\
\text { Problemleri }\end{array}$} & $\begin{array}{l}\text { Yalan } \\
\text { söyleme }\end{array}$ & $\checkmark$ & & & & & & & & 1 \\
\hline & Ağlama & & $\checkmark$ & & & & $\checkmark$ & & & 2 \\
\hline & Kekemelik & & & $\checkmark$ & & & & & & 1 \\
\hline & $\begin{array}{l}\text { Anne-babaya } \\
\text { bağımlılık }\end{array}$ & $\checkmark$ & & & & & $\checkmark$ & $\checkmark$ & & 3 \\
\hline & $\begin{array}{l}\text { Sürekli } \\
\text { şikâyet etme }\end{array}$ & & & & & & $\checkmark$ & $\checkmark$ & $\checkmark$ & 3 \\
\hline & Paylaşmama & & & & & & & & $\checkmark$ & 1 \\
\hline
\end{tabular}

(Ö: Öğretmen; Ç: Çocuk)

Tablo 4 incelendiğinde, öğretmenlerin, öz düzenleme becerileri gelişmemiş çocukların gösterdikleri davranış sorunlarına ilişkin görüşlerini saldırganlık, kurallara uymama, grup dinamiğini bozma ve diğer davranış problemleri olmak üzere dört kategoride belirttikleri görülmektedir. Tablo incelendiğinde, öğretmenlerin öz düzenleme becerileri gelişmemiş çocuklarda en çok karşılaştıkları davranış problemlerinin, çabuk sıkılma/sebat etmeme, yönergelere uymama, sorumluluk almama/yerine getirmeme olduğu görülmüştür. Bununla birlikte öz düzenleme becerileri gelişmemiş çocukların daha çok kurallara uymama ve grup dinamiğini bozma kategorisine ait davranışlarda sorun yaşadıkları görülmüsstür. Öğretmenlerin öz düzenleme becerisi gelişmemiş çocuklara ilişkin bazı görüşleri şu şekildedir: 
Okul Öncesi Dönem Çocuklarının Davranışlarının Öz Düzenleme Becerileri Yönünden İncelenmesi

"Etrafindakileri dinlemez, şiddet uygulamaz, ama sözel şiddet uygular, baskı yapar... Tek başına oynamaz, kurulu oyunun içine girmeye çalışır... Düzenini bozar arkadaşlarının ...Kuralları tanımaz, sürekli ben hatırlatmak zorunda kalıyorum... Hikaye hiç dinlemez, hep başka şeyle ilgilenir... Yanındakilerin de dikkatini dă̆ıtır. ” (Ö3)

“...Oyun etkinliğinde kendini sürekli yere atar... Beni duymazlıktan gelir... Faaliyeti bittiğinde arkadaşlarını rahatsız eder... Etkinlik sürecini olumsuz etkiler.” (Ö1)

"Bireysel etkinlikleri sever, çok ısrarcıdır. Kural olan bir şey için ısrarcı davranır... Sabırsız..." (Ö2)"

"Hareketli ve hayal gücü kuvvetli... Kabus görüyor sürekli... Sürekli konuşur, rahatsız eder, canavarlardan konuşur... Sürekli hareket etmek ister...Çabuk sıkılır, sürekli ikaz ediyorsun, etkinlik sırasında ayă̆a kalkar. Bizi korkutmaya çalışır, sürekli canavar yollayacă̆ım diyor... Beni duymazlıktan geliyor, duyuyor ama tepki vermiyor... İstediği şeyi yaptırmak için yumuşak davranır." (Ö4)

Tablo 5'e göre, sekiz çocuktan yedisinin var olmayan hayvanı için bir isim belirlediği, bir çocuğun ise hayvanına isim vermek istemediği görülmüştür. Çocukların hayvanları oluşturma yetenekleri incelendiğinde, dört çocuğun farklı hayvanların çeşitli organlarını kullanarak karma hayvan resmi türünde çizim yaptıkları, dört çocuğun ise genel yapı olarak gerçek hayvan şekline benzeyen, ancak çizilen organlarla gerçek hayvanlardan ayrılan çizimler yaptıkları görülmüştür. Çocukların çizimleri incelendiğinde tüm çocukların resimlerinde kâğıdı yatay olarak kullandıkları görülmektedir. Beş çocuğun, resminde saldırganlığı temsil eden ögeler kullanmalarına karşın, yedi çocuğun çizdiği hayvanın özelliklerini anlatırken saldırganlık ögelerine yer verdikleri görülmüştür. Sadece bir çocuğun çizdiği hayvan için saldırgan özellikler belirtmediği (boynuz ifadesini kullanmasına karşın bunu kötü durumda olanlara yardım etmek amacıyla güç elde etmek için kullandığını belirtmiştir), bu çocuğun da çalışma grubundaki tek kız olduğu belirlenmiştir. Bununla birlikte beş çocuğun resimlerinde hayvan dişında başka öğelere de yer verdikleri (örümcek, uçan dragon, silahlı insanlar vb.) görülmüştür. $\mathrm{Bu}$ çocukların çizdikleri var olmayan bir hayvan ile birlikte farklı ögeler de çizerek bir kompozisyon oluşturma eğiliminde oldukları gözlemlenmiştir. 
Tablo 5

Öz düzenleme Becerisi Gelişmemiş Çocuklarin "Var Olmayan Hayvan Çiz Testine” Ait Resimlerinin Analizi

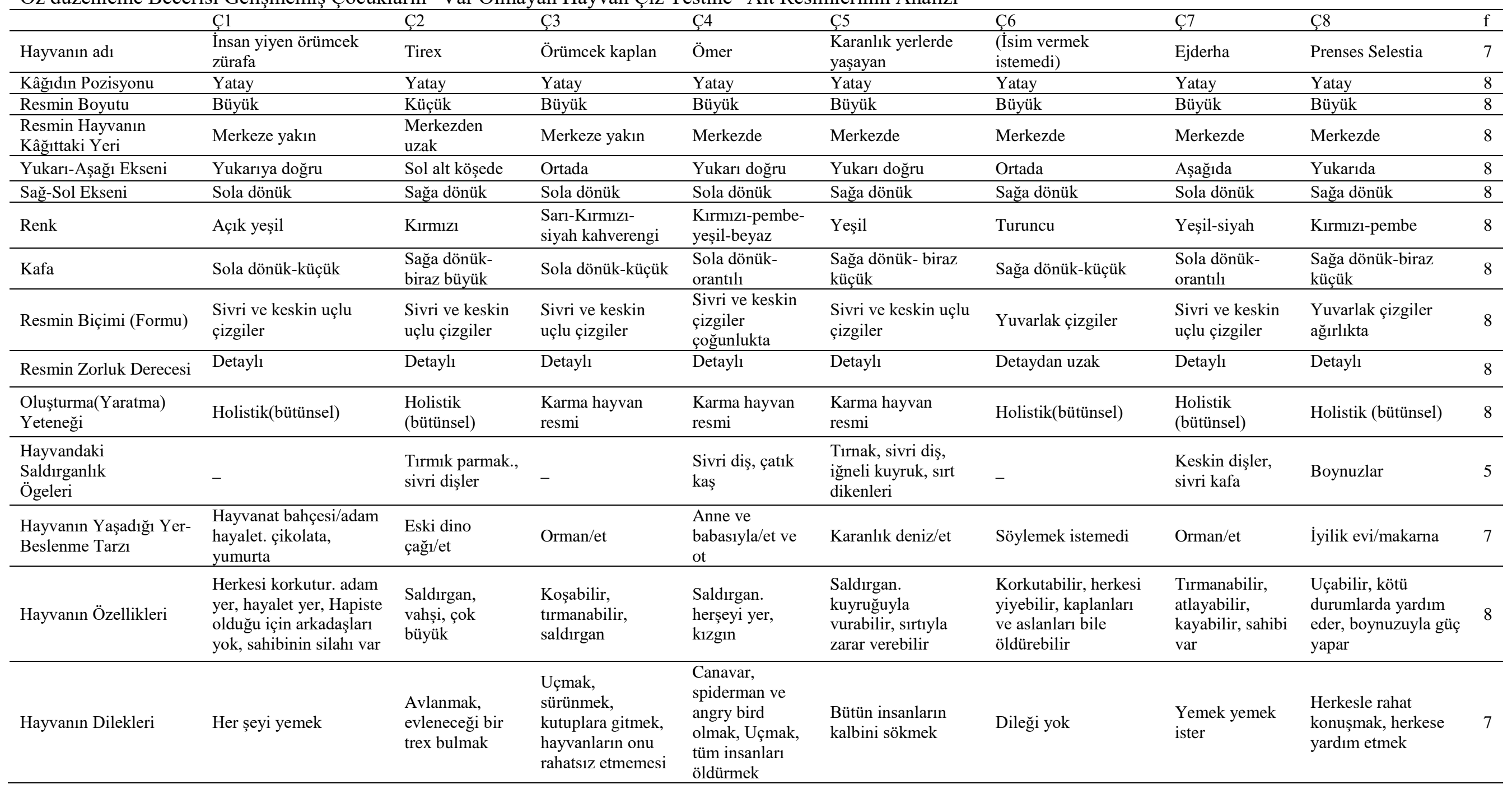


Aşağıda, çocukların "Bir hayvan çiz testi”" ne ilişkin çizdikleri resimlerden çizimlerinde saldırganlı̆̆ 1 belirgin olarak yansıttığı/saldırganlık ögelerine yer verdiği belirlenen dört çocuğun resmine yer verilmiştir:

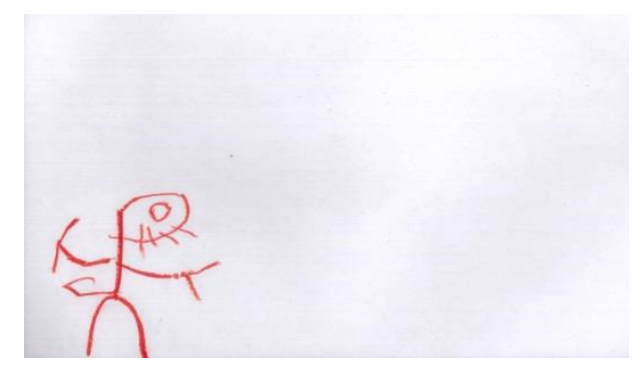

Ç2 (Tirex)

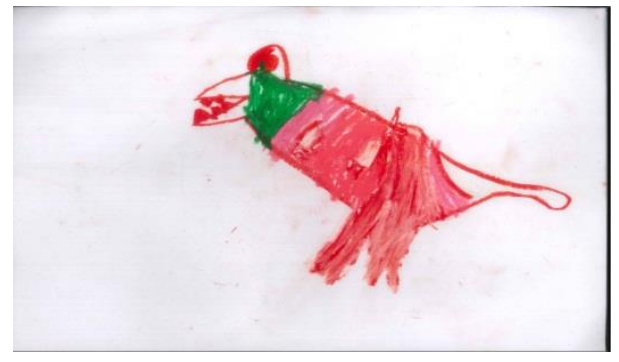

Ç4 (Ömer)

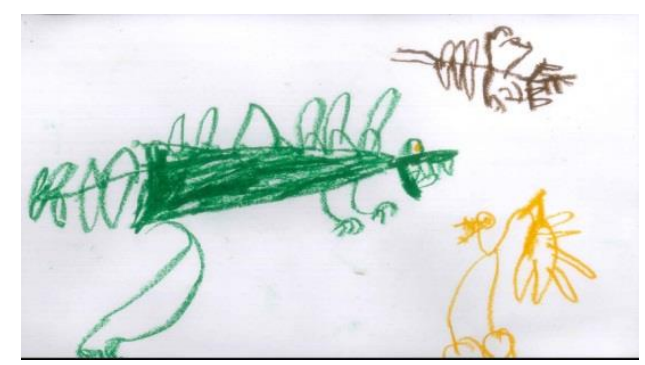

Ç5 (Karanlık yerlerde yaşayan)

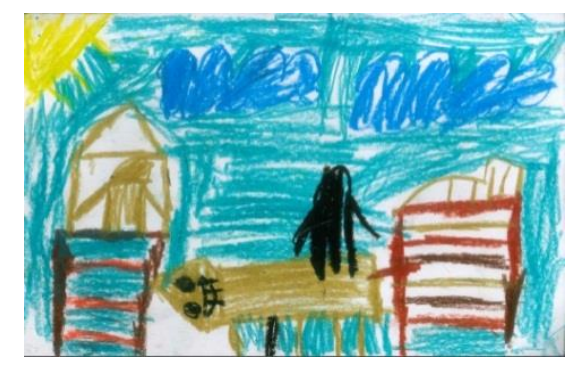

Ç7 (Ejderha)

Çocukların örnek olarak sununlan resimleri incelendiğinde, resimlerin saldırganlık ögeleri içerdiği görülmektedir. Bir çocuğun sivri diş ve parmaklar çizdiği görülürken (Ç2), bir çocuğun resminde sivri dişler, çatık kaş çizdiği (Ç4) görülmektedir. Bir başka çocuğun çizdiği resimde sivri tırnaklar, keskin dişler, iğneli kuyruk ve sırt dikenlerine yer verdiği (Ç5), diğer çocuğun keskin dişler ve sivri kafa çizdiği (Ç7) görülmektedir. Çocukların yaptıkları resimlerle ilgili açıklamaları şu şekildedir:

"Eski çağlarda yaşar, iki parmağı var, eli yok. Dişleri çok sivri... Çok iyi avlanır... Saldırgan, vahşi, çok büyük. Avlanmak ister, evleneceği bir tirex arar” (Ç2)

"Çimen ve et yer, Saldırgan, kuyruğuyla vurur, sırtıyla hayvanlara zarar verir... En çok eti sever... Yanındakiler hem dostları hem düşmanları" (Ç5)

"Saldırgan bir hayvan, her şeyi yiyebilir, kızgın... Annesi ve babasıyla yaşıyor... Arkadaşları var; Duru ve Efe... Canavar, Spiderman, Angrybird olmak istiyor. Bütün kahramanlarl olmak istiyor ... Uçmak ve tüm insanlarl öldürmek istiyor. ” (Ç4)

"Sivri kafa duvarı yıkmaya çalışıyor...Orada hapis bir insan var...Dişleri çok keskin” (Ç7)

\section{Tartışma}

Araştırma sonuçları incelendiğinde, elde edilen nicel ve nitel verilerin birbiriyle örtüştüğü görülmüştür. Buna göre, nicel boyutta öz düzenleme becerileri ölçeğinden düşük puan alan çocukların, nitel boyutta da öğretmen görüşlerine ve çizdikleri resimlere göre problemli davranışlar sergilemeye daha eğilimli oldukları belirlenmiş̧tir.

Araştırmanın bulguları doğrultusunda, öğretmenlerin görüşlerine göre, öz düzenleme becerileri gelişmemiş çocukların daha çok kurallara uymama ve grup dinamiğini bozma kategorisine ait davranışlarda sorun yaşadıkları belirlenmiştir. Bu çocukların en fazla çabuk sıkılma/sebat etmeme, yönergelere uymama ve sorumluluk almama/yerine getirmeme davranış 
sorunlarını gösterdikleri görülmüştür. Okul öncesi dönemde öz düzenleme becerilerinde zorluk yaşayan çocuklar, orta çocukluk ve ergenlikte duygusal sorunlar ve davranış problemleri yaşamaktadırlar (Savina, 2016). Seçer ve diğerleri (2009) çalışmalarında impulsif (içtepisel) çocukların akranlarına göre sınıf içinde daha fazla dikkat eksikliği, dürtüsel, saldırgan ve antisosyal davranışlar gösterdiklerini bulmuşlardır. Montroy ve diğerleri (2014) de okul öncesi dönemdeki çocuklarla yaptıkları çalışmada, gelişmemiş öz düzenleme becerilerine sahip çocukların problemli davranışlar göstermeye daha eğilimli olduklarını belirtmişlerdir. Koçyiğit ve diğerleri (2015) çocukların duygu düzenleme becerileri arttıkça oyun becerilerinin de arttığını bulmuşlardır. Harter ve Pike (1984), okul öncesi dönemde en yaygın biçimde ele alınan sosyal-duygusal yeterlik göstergelerinin akranları tarafindan kabul edilme ve oyunlarda tercih edilme olduğunu belirtmişlerdir. Bu bulgular öz düzenleme becerileri gelişmiş çocukların akran ilişkilerinde de daha başarılı olduklarını gösterir niteliktedir. Hazzı ertelemede daha iyi olan çocukların gerginlik yaratan durumlarda tepkilerini ve duygularını düzenleyebildikleri, ayrıca dikkat düzeylerinin de daha iyi olduğu belirlenmiştir (Rothbart ve Sheese, 2007). Hrbackova ve Safrankova (2016) kurumsal ve doğal çevredeki 2.776 çocuk ve ergenin öz düzenleme davranışlarını inceledikleri çalışmalarında, çocukların problem davranışları ile öz düzenlemeleri arasında ilişki bulmuşlardır. Bununla birlikte, çocukların problem davranışları arttıkça duygu düzenleme becerilerinin de azaldığı belirlenmiştir.

Araştırmanın diğer bulgusunda, öz düzenleme becerileri gelişmemiş olan sekiz çocuktan yedisinin erkek olduğu belirlenmiştir. Yapılan bazı araştırmalarda (Kochansha, Murray ve Coy, 1997; Raffaelli ve diğerleri, 2005) kızların öz düzenleme becerilerinin erkeklerden daha gelişmiş olduğu belirlenirken, ülkemizde yapılmış çalışmalar (Ertürk Kara ve Gönen 2015; Fındık Tanrıbuyurdu, 2012) cinsiyet ve öz düzenleme arasında ilişki olmadığını göstermiştir. Bununla birlikte Özdemir ve Tepeli (2015), araştırmalarında, okul öncesi eğitim kurumlarında fiziksel saldırganlığın ilişkisel saldırganlığa oranla daha çok görüldüğünü ve fiziksel saldırganlığın daha çok erkeklerde, ilişkisel saldırganlığın ise kızlarda daha fazla ortaya çıktığını belirlemişlerdir. $\mathrm{Bu}$ araştırmada da problem davranış olarak daha çok fiziksel saldırganlığın görülmesi ve ilişkisel saldırganlığın sadece kız çocukta görülmesi araştırmanın bulgularını destekler niteliktedir. Bu durum, kızların daha işlevsel bir tepki planlamak ve uygulamak adına baskın ve reaktif bir tepkiyi gönüllü olarak bastırma kapasitesi olarak tanımlanan çaba gerektiren kontrolde (Berk, 2013) avantajlı olmalarıyla, işbirliği becerisini daha iyi geliştirmeleriyle, okul performanslarının daha iyi olmasıyla ve daha az davranış problemi yaşamalarıyla açıklanabilir (Else-Quest ve diğerleri, 2006).

Araştırmanın bir diğer bulgusuna göre, çocukların "var olmayan bir hayvan" resimlerinde, beş çocuğun çizimlerinde saldırganlık belirten ögeler (tırnak, sivri diş, diken vb.) kullandıkları, yedi çocuğun ise resimlerini anlatan söylemlerinde saldırganlık özelliğine sahip hayvanlar (korkutan, vahşi, insan yiyen vb.) çizdikleri belirlenmiştir. Okyay (2008) çalışmasında, çocukların davranış problemleri ile çizdikleri resimlerde kullandıkları figürler, çevre detayları ve renkler arasında ilişki olduğunu bulmuştur. Resim, bireyin hayata bakış açısı ile ilgili olduğundan, resim yapanın kişilik özelliklerinin yanı sıra o bireyin, hayatın farklı yönleriyle ilgili tutumları hakkında da bilgi vermektedir (Halmatov, 2015). Çocuklar hayvanları hiç görmemiş olsalar bile, hayvanlar onlara onlara tanıdık gelir. Çocuğun hayvanlarla karşılaşması duygusal ilişki kurması demek olduğundan, çocuk bu yolla duygusal sorunlarını bilinçdışı yoluyla maskeleyebilir, hatta sansürleyebilir. Aslında hayvan, çocuğu ve onun dış dünyayla olan ilişkilerini temsil eder. Görünüsşte uyumlu bir çocuk, özellikle saldırganca duygularını, ilk bakışta sıradan görünen, oysa birçok ipucu içeren bir hayvan resmiyle gizleyebilir (Davido, 2014). Bunun yanında araştırmada, beş çocuğun, resimlerinde, var olmayan hayvan dışında başka ögelere de yer verdikleri görülmüştür. Bu durum, çocukların bu davranışlarının dürtü kontrolüyle ilgili olabileceğini düşündürmüştür.

Ayrıca, çocukların resimleriyle ilgili ifadeleri incelendiğinde, bir çocuğun (Ç4) ifadesinde hayvanın arkadaşları olarak kendi arkadaşlarının ismini vermesi ve anne babasıyla yaşadığını belirtmesi dikkat çekicidir. Bu, çocuğun çizdiği hayvanla, kendisini özdeşleştirdiğini doğrular niteliktedir. 


\section{Sonuç ve Öneriler}

Araştırmanın sonucunda, öz düzenleme becerisi gelişmemiş çocukların davranış sorunları göstermeye eğilimli oldukları ortaya çıkmıştır. Buna gore, gelişmemiş öz düzenleme becerisine sahip olan çocukların daha çok kurallara uymama ve grup dinamiğini bozma kategorisine ait davranışlarda sorun yaşadıkları belirlenmiştir. Yine araştırmanın nitel boyutundaki bir başka bulgusuna göre, öz düzenleme becerisi gelişmemiş olarak belirlenen sekiz çocuktan yedisinin erkek olması dikkat çekmiştir.

Çocuğun gelişimi bir bütündür, dönem dönem gelişir, ancak her dönem kendinden önceki dönemden olumlu ve olumsuz olarak etkilenir. Bu olumsuz durumlar gelişimin bir döneminden itibaren uzun süre devam ederse ve ileriki yaşamında bu olumsuzlukları giderecek koşullar oluşmazsa, bu birikim ve sürekliliğin çocuğu etkileme olasıllı̆ı büyük olur (Ekşi, 2010). Çocukların erken dönemlerden itibaren öz düzenleme becerilerini desteklemek çocuk ve ergenlerdeki riskli davranışları önlemek için büyük önem taşımaktadır. Bu nedenle konuyla ilgili öneriler şu şekilde sıralanabilir:

- Çocukların öz düzenleme becerilerine yönelik etkinlik önerileri içeren ve öğretmen uygulamaları öneren "zihnin araçları" gibi programlarla (Aras, 2015) erken dönemde çocukların öz düzenlemeleri desteklenmelidir.

- Ülkemizdeki boylamsal çalışmaların eksikliği dikkate alındığında, çocukların öz düzenleme becerileri ile uzun dönemli davranış sorunlarını ortaya çıkaracak boylamsal çalışmalar yapılabilir.

- Resimler, çocukları anlamada etkili yöntemler olduğundan resim çizme tekniğinin kullanıldığı testler (aile çiz testi, bir kaktüs çiz testi vb.), çocuklarla yapılan çalışmalarda araştırmacılar tarafından tercih edilebilir.

Her çocuğun özel olduğu düşünüldüğünde, öğretmenlerin ve ailelerin öz düzenleme becerileri gelişmemiş olan çocuğa yaklaşımları da çocuğa özgü olmalıdır. "Bir çocuğu büyütmek için bir köy gerekir" (Berk, 2013), Afrika atasözünden yola çıkarak çocuğu desteklemenin sadece öğretmenlerin değil, ailenin ve çocukla etkileşim halinde olan diğer kişilerin de sorumluluğu kapsamında olduğu unutulmamalıdır.

\section{Kaynaklar}

American Psychological Association [APA]. (2013). Amerikan psikiyatri birliği DSM-5 tanı ölçütleri başvuru el kitabı. (E. Köroğlu, Çev.). Ankara: Hekimler Yayın Birliği.

Akduman, G. G. (2014). Çocuklarda görülen uyum ve davranış sorunları. A. Güngör Aytar (Yay. haz.). Çocuk ruh sağlı̆̆

Alisinanoğlu, F. ve Kesicioğlu, O. S. (2010). Okul öncesi dönem çocuklarının davranış sorunlarının çeşitli değişkenler açısından incelenmesi (Giresun İli Örneği). Kuramsal Ĕ̈itimbilim, 3(1), 93-110.

Aras, S. (2015). Promoting self-regulation in early years: Tools of the mind. Journal of Education and Future, 8, 15-25.

Aunola, K. ve Nurmi J. E. (2005). The role of parenting styles in children's problem behavior. Child Development, 76(6), 1144-1159.

Berk, L. E. (2013). Bebekler ve çocuklar: Doğum öncesinden orta çocukluğa (N. Işıkoğlu Erdoğan, Çev. Ed.). Ankara: Nobel.

Berk, L. E. (2013). Çocuk gelişimi (B. Onur. ve A. Dönmez, Çev.). Ankara: İmge.

Bodrova, E. ve Leong, D. J. (2013). Zihin araçları: Erken çocukluk eğitiminde Vygotsky yaklaşımı. G. Haktanır (Yay. Haz.). Ankara: Anı Yayıncılık.

Creswell, J. W. (2014). Araştırma deseni. (S. B. Demir, Çev Ed.). Ankara: Eğiten Kitap.

Çağdaş, A. ve Seçer, Z. (2002). Çocuk ve ergende sosyal ve ahlak gelişimi, R. Arı (Yay. haz.). Ankara: Nobel.

Davido, R. (2014). Çocuğunuzu resimlerinden keşfedin (E. Çakmak, Çev.). İstanbul: Kuraldışı. 
Dursun, A. (2010). Okul öncesi dönemdeki çocukların davranış problemleriyle anne-baba tutumları arasındaki ilişkinin incelenmesi (Yayımlanmamış doktora tezi). Erişim adresi: http://tez.yok.gov.tr

Eisenberg, N., Pidada. S. ve Liew. J. (2001). The relations of regulation and negative emotionality to Indonesian children's social functioning. Child Development, 72, 17471763.

Eisenberg, N., Smith, C. L. ve Spinrad, T. L. (2004). Effortful control: Relations with emotion regulation adjustment and socialization in childhood. Erişim adresi: https://www.researchgate.net/publication/232597527

Eisenberg, N., Spinrad, T., Fabes, R., Reiser, M., Cumberland, A. ve Shepard, S. (2004). The relations of efforful control and impulsivity to childrens' resiliency and adjustment. Child development, 75, 25-46.

Ekşi, A. (2010). Çocukluk döneminde uyum ve davranış sorunları. A. Ekşi (Yay. haz.). Ben hasta değilim içinde (s. 98-125). Ankara: Nobel.

Else-Quest, N. M., Hyde, J. S., Goldsmith, H. H. ve Van Hulle, C. A. (2006). Gender differences in temperament: A meta analysis. Psychological Bulletin, 132, 33-72.

Ertürk Kara, H. G. ve Gönen, M. (2014). Okul öncesi dönemdeki çocukları öz düzenleme becerisinin çeşitli değişkenler açısından incelenmesi. Ĕ̆itimde Kuram ve Uygulama, 11(4), 1224-1239.

Fındık Tanrıbuyurdu, E. ve Güler Yıldız, T. (2012). Okul öncesi öz düzenleme ölçeği geçerlik ve güvenirlik çalışması (Yüksek lisans tezi). Erişim adresi: http://tez.yok.gov.tr

Fındık Tanrıbuyurdu, E. ve Güler Yıldız, T. (2014). Okul öncesi öz düzenleme ölçeği (OÖDÖ): Türkiye uyarlama çalışması. Eğitim ve Bilim, 39(176), 317-328. doi: 10.15390/EB.2014.3647

Halmatov, S. (2015). Çocuk resimleri analizi ve psikolojik resim testleri. Ankara: Pegem Yayınc1lik.

Harter, S. ve Pike, R. (1984). The pictorial scale of perceived competence and social acceptance for young children. Child Development, 55(6), 1969-1982.

Hrbackova, K. ve Safrakova, A. P. (2016). Self-regulation of behavior in children and adolescent in the natural and instituonal environment. Social and Behavioral Sciences, 217, 679-687.

Johnson, B. ve Christensen, L. (2014). Nitel, nicel ve karma yöntem yaklaşımları: Eğitim araştırmaları (S. B. Demir, Çev. Ed.). Ankara: Eğiten Kitap.

Kırışoğlu, O. T. (2005). Sanatta ĕğitim görmek, öğrenmek, yaratmak. Ankara: Pegem.

Kochanska, G., Murray, K. ve Coy, K. C. (1997). Inhibitory control as a contributor to conscience in childhood: From toddler to early school age. Child Development, 68(2), 263-277.

Kandır, A. (2000). Öğretmenlerin beş-altı yaş çocuklarında görülen davranış problemlerine ilișkin bilgi ve tutumları. Gazi Üniversitesi Mesleki Eğitim Fakültesi Dergisi, 2(1), 42-50.

Kanklıkılıçer, P. (2005). Okul öncesi davranış sorunları tarama ölçeği geçerlilik güvenirlik çalışması (Yayımlanmamış yüksek lisans tezi). Marmara Üniversitesi, İstanbul.

Kılıççı, Y. (2000). Okulda ruh sağlı̆̆ı. Ankara: Anı.

Koçyiğit, S., Sezer, T. ve Yılmaz, E. (2015). 60-72 aylık çocukların sosyal yetkinlik ve duygu düzenleme becerileri ile oyun becerileri arasındaki ilişkinin incelenmesi. Hasan Ali Yücel Eğitim Fakültesi Dergisi, 12(1), 209-218.

Livanage, K. C., Prince, M. J. ve Scott, S. (2003). Mother-child joint activity and behavior problems of preschool children. Journal of Child Psychology Psychiatry, 44(7), 10371048.

Malchiodi. C. A. (2013). Çocukların resimlerini anlamak (T. Yurtbay, Çev. Ed.). İstanbul: Nobel.

Mccelland, M. M. ve Tominey. S. L. (2011). Introduction to do special issue on self regulation in early childhood. Early Education and Development, 22(3), 355-359.

Merriam, S. B. (2015). Nitel araştırma (S. Turan, Çev. Ed.). Ankara: Nobel. 
Okul Öncesi Dönem Çocuklarının Davranışlarının Öz Düzenleme Becerileri Yönünden İncelenmesi

Nota, L., Soresi, S. ve Zimmerman, B. J. (2004). Self-regulation and academic achievement andresilience: A longitudinal study. International Journal of Educational Research. 41, 198-215.

Miles, M. B. ve Huberman, A. M. (2015). Nitel veri analizi. (S. Akbaba Altun ve A. Ersoy, Çev. Ed.). Ankara: Pegem.

Montroy, J. J., Bowles, P. P., Skibbe, L. L. ve Foster. T. D. (2014). Social skills and problem behaviors as mediators of the relationship between behavioral self-regulation and academic achievement. Early Childhood Research Quarterly, 29, 298-309.

Okyay, L. (2008). 6 yaş grubu çocukların aile resimlerinin sosyo-kültürel değişkenler ve davranış problemleri açısından karşılaştırılması (Yayımlanmamış yüksek lisans tezi). Trakya Üniversitesi, Edirne.

Özdemir, S. ve Tepeli, K. (2015). Okul öncesi çocuklarda görülen fiziksel ve ilişkisel saldırganlık davranışlarının incelenmesi. Uluslararası Avrasya Sosyal Bilimler Dergisi, 6(18), 229-245.

Patton, M. Q. (2014). Nitel araştırma ve değerlendirme yöntemleri (M. Bütün ve S. B. Demir, Çev. Ed.). Ankara: Pegem Akademi.

Polnariev, B. A. (2006). Dynamics of preschoolers self-regulation: Viewed through the lens of conflict resolution strategies during peer free-play (Unpublished dissertation thesis). Erişim adresi: ProQuest.

Raffaelli, M., Crockett, L. S. ve Shen, Y. L. (2005). Developmental stability and change in selfrugulation from childhood to adolescence. The Journal of Genetic Psychology, 166(1), 54-75.

Rothbart, M. K. ve Sheese, B. E. (2007). Temperament and emotion regulation. J. J. Gross (Yay. haz.). Handbook of the emotion regulation içinde (s. 331-350). New York: Guilford Press.

Savina, E. (2016). Does play promote self-regulation in children? Early Child Development and Care, 184(11), 1692-1705.

Seçer, Z., Çeliköz, N., Koçyiğit, S., Seçer F. ve Kayılı, G. (2009). Social skills and problem behaviour of children with different cognitive styles who attend preschool education. Procedia Social and Behavioral Sciences, 1, 1554-1560.

Senemoğlu, N. (1994). Okul öncesi eğitim programı hangi yeterlilikleri kazandırmalıdır? Hacettepe Ĕ̈itim Fakültesi Dergisi, 10, 21-30.

Sternberg, R. J. ve Spear-Swerling, L. (1998). Personal navigation. M. Ferrari ve R. J. Sternberg (Yay. haz.). Self awareness: Its nature and development içinde. New York: The Guilford Press.

Yavuzer, H. (1997). Çocuk psikolojisi. İstanbul: Remzi Kitabevi.

Yavuzer, H. (2007). Resimleriyle çocuk. İstanbul: Remzi Kitabevi.

Yıldırım, A. ve Şimşek, H. (2013). Sosyal bilimlerde nitel araştırma yöntemleri. Ankara: Seçkin Yayıncilik.

Yörükoğlu, A. (2008). Çocuk ruh sağllğg. İstanbul: Özgür Yayınevi.

Whitebread, D., Anderson, H., Coltman, P., Page, C. Pino Pasternak, D. ve Metha, S. (2004). Metacognition in young children: evidence from a naturalistic study of 3-5 year olds. [Full text]. Paper Presented at First Meeting of The Early Metacognition Special Interst Group, Amsterdam. Erişim adresi: https://www.educ.cam.ac.uk

Zimmerman, B. J. (1990). Self-regulated learning and academic achievement: An overview. Educational Psychologist, 25(1), 3-7.

Zimmerman, B. J. (2000). Attaining self-regulation: A social cognitive perspective. P. M. Boekaerts ve M. Zeidner (Yay. haz.). Handbook of self regulation içinde (s. 13-39). Orlando. FL: Academic Press. 


\section{Extended Abstract}

\section{Introduction}

Self-regulation refers to an individual's controlling of his/her learning process in cognitive, motivational and behavioral terms. A child whose self-regulation is developed prevents the improper behavior and shows appropriate behavior. Children whose self-regulation is developed can postpone enjoyment, give up an aggressive behavior and show positive behaviors by controlling their emotions. On the other hand, children whose self-regulation is weak may show delays in the mental development, and have behavioral problems in the preschool years. These children are at risk in terms of long lasting problems. In this study, it is aimed to investigate behavior of children whose self regulation is not developed based on the opinion of teachers and children's drawings.

\section{Methodology}

In this study mixed model and exploratory sequential design was used. In the quantitative part of the study, survey design was used. In the qualitative part case study design was used. This study incorporated a holistic multiple-case study design in which each case is considered as a whole and later compared to each other. The study group for the qualitative part of this study was composed of 64 children who were at the age of 60 to 72 months and attending to kindergartens at center in province of Ankara during the data collection On the other hand, in the qualitative part of the study eight children were selected being two lowest scorers from the self-regulation scale in each classroom. A semi-structured interview was conducted with the teachers of these children, as well as the "nonexistent animal drawing test" was applied to these children. For the quantitative part of the study, survey design was used, and a descriptive analysis was conducted through SPSS 16 package program.

\section{Results}

At the end of the study, based on their teachers' views, children whose self-regulation skills are not developed were found to be experiencing problems more in violating the rules and ruining the group dynamics categories. At the end of the study, these children were found as exhibiting mostly the following behaviors as getting bored quickly/impersistence, violating the directions and avoiding responsibility/nonfulfillment. In another finding of the study, it is found out that seven of the eight children were male whose self-regulation was not developed. In a final finding of the study while five of the children's nonexistent animal drawings included aggression, seven of the students expressed that they drew aggressive animals in their verbal explanation of their drawings.

\section{Discussion and Conclusion}

A child's development is a whole, it develops in periods, but each period is affected from the preceding period either in a negative or positive way. If these negative situations maintain for a long time after a certain development process, and if the conditions to compensate these do not form in the life of the child, the possibility of the child being affected by this accumulation and continuity is high. It was found out that the self-regulation skill gained in the preschool period continues during childhood and puberty periods. Supporting self-regulation skills of children starting from early ages is important in terms of preventing the risky behaviors during puberty. Therefore, children's self-regulations should be supported at the early periods through designing programs which include proposed activities towards developing self-regulation of the children. 